\title{
Leadership election reform in the British Labour party: democratisation or power struggle?
}

\section{Tim Niendorf ${ }^{1}$}

Accepted: 29 September 2021 / Published online: 16 October 2021

(c) The Author(s) 2021

\begin{abstract}
This article examines the impact of reforms on the outcome of Labour party leadership contests since the premiership of Tony Blair. From a theoretical perspective, these reforms are characterised by a tension between a general trend towards increasing "democratisation" of political parties and the power interests of intraparty actors. While there have been significant changes to both the nomination stage and the final ballot, the impact of these changes has to be strongly qualified. Instead of a major "democratisation" through targeted and deliberate reform measures, simple shifts in the power structure between strategic actors are more prominent among reform effects. Meanwhile, the trend towards "democratisation" in relation to the final ballot stage was largely driven by the massive membership surge since 2015, as well as low-key reform measures unconnected to handing ordinary party members more influence over the election process.
\end{abstract}

Keywords Labour party · Leadership elections · Trade unions · Ed Miliband · Jeremy Corbyn · Party reform

\section{Introduction}

With Keir Starmer's election as new Labour leader on 4 April 2020, the party selected its fourth leader in just ten years. But it was not just the person of the leader that had seen considerable fluctuation since the last Labour government, the same is true of the rules guiding these elections. According to Tom Quinn (2018, p. 474), the party had gone through an impressive number of 12 leadership election reforms since its last opposition spell in the 1980s. This is a highly unusual phenomenon since Chiru et al (2015, pp. 39-40) show that such changes are very rare, with Labour easily falling into their highest reform likelihood category. In addition, none of the leadership elections since the New Labour era (2007, 2010, 2015, 2016, 2020)

Tim Niendorf

tim.niendorf@uni-jena.de

$1 \quad$ Friedrich-Schiller-University Jena, 07737 Jena, Germany

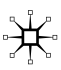


were held under the same set of rules as the previous, except for 2007 and 2010 (Quinn 2018, pp. 476-480).

The seemingly high volatility of the electoral rules, the ideological profile of the elected leaders and the high frequency of elections itself all warrant a variety of questions about Labour's handling of leadership elections in the past 20 years (Quinn 2018, pp. 480-481, Heppell 2010a, pp. 196-197). This paper tries to address one aspect of this complex issue that has so far received comparatively little attention. It concerns the consequences of leadership election reform, and more specifically, what we can learn from the impact of reforms on election outcomes about the motivation of reformers. The research on this topic shows a clear tension between the institutional conservativeness of political parties and a general trend towards a "democratisation" of intra-party elections (Cross and Blais 2012a, pp. 82-85, 2012b, pp. 128-129; Kenig 2008, p. 241; Kenig et al. 2015a, pp. 33-34; Chiru et al. 2015, pp. 32-33). Looking at how much reforms have increased both the open-endedness of leadership elections and members' influence on them might indicate whether the reforms were driven by the particularistic interests of powerful established actors or more holistic concerns about the party as a whole.

The paper is divided into five sections. The first section will outline the main research goal in more detail. The second section discusses Labour's internal power structure, identifying strategic actors with vested interests in particular reforms. The third section gives an overview of the content of the three major leadership election reforms of the 2010s. The fourth section looks at how these reforms changed the influence of strategic actors on the outcome of leadership elections. The final section focuses on whether the impact of the reforms indicates an increasing "democratisation" of leadership elections or "ordinary" shifts in the party's internal power structures.

\section{Motivations for leadership reform}

While party leadership reform has only recently received broader attention as a topic of international comparison, especially through the extensive research around the COSPAL group (Cross and Blais 2012a, b; Hazan and Rahat 2010; Lisi et al. 2015; Chiru et al. 2015; Kenig et al. 2015b), it has been a research subject with a long tradition in the UK. Beginning with the seminal studies of the 1970s to early 1990s by Drucker (1976, 1981, 1984), Punnett (1990, 1992, 1993), Alderman and Carter (1991, 1993, 1995), it has created an extensive body of literature (specifically for the Labour party see Quinn 2018, 2016, 2012, 2004; Jobson and Wickham-Jones 2011; Bale and Webb 2014; Dorey and Denham 2016, 2011; Denham and Dorey 2018; Heppell et al. 2021; Heppell 2021, 2010a, 2010b; Crines et al. 2018; Stark 1996). This raises the question of what can still be learned from such an analysis, both specifically for the Labour party as well as party leadership elections in general. Since the debates surrounding this topic are manifold and wide-ranging, I want to focus on two major issues with a closer connection to the subject of this article.

When looking specifically at the British studies, we can identify two different strands of research. The larger part typically deals with reviewing the outcomes of 
either one or multiple elections and tries to explain how the results came about (for example Dorey and Denham 2016, 2011, Jobson and Wickham-Jones 2011, Quinn 2016, Heppell et al. 2021, Heppell 2021, Crines et al. 2018). The second part is more focussed on outlining structural features' consequences for the electoral process or their influence on other organisational aspects (for example Quinn 2018, 2004, Stark 1996, Heppell 2010b, Pemberton and Wickham-Jones 2015). Both approaches are, however, strongly influenced by the seminal work of Leonard Stark (1996). In his comparative analysis of leadership contests since 1963 he reaches a number of conclusions which have either a direct impact or are at least used as contra points to justify deviating analytical approaches in the UK (Crines et al 2018; Heppell 2010a, 2021; Dorey and Denham 2016, 2011; Quinn 2016; Bale and Webb 2014). Stark's (1996, pp. 124-131 and 137-138) major argument of relevance here is the existence of a universally shared hierarchy of interests among all potential electors when choosing a party leader. This means that both electoral rules and individual leadership campaigns are almost entirely meaningless in shaping the outcome of such elections or, in more general terms, that "institutions don't matter" (Stark 1996, pp. 117-121 and 131-134).

However, despite the lack of institutional impact, Stark argues that different intraparty actors are still highly concerned about the design of the rules under which elections are conducted (Stark 1996, pp. 64-66). For the Labour party this observation is further supported by Heppell (2010a, pp. 196-198, also see Quinn 2018, pp. 480-481), who argues that the high frequency of leadership elections and recurring reforms of electoral procedures after the resignation of Harold Wilson were facilitated by the increasing factionalism and power struggles between warring sections of the party. Therefore, irrespective of the supposedly negligible impact of rules on the outcome of leadership elections, the involved actors consider them as an important battleground of intra-party power distribution.

If we now look at the comparative international research on the topic, we can see that much of the literature is either concerned with the reasons of why certain people get elected and how institutional configurations influence elections (Rahat et al 2008; Cross and Blais 2012a; Kenig 2008; LeDuc 2001; Pilet and Cross 2014; Kenig et al 2015b; Hazan and Rahat 2010) or under which conditions reforms take place (Cross and Blais 2012b; Lisi et al 2015; Chiru et al 2015). However, a far less prominent subject concerning the second approach is the question of what actors want to achieve by changing the rules or, more abstractly, the motivational dimension of the issue (a notable exception is Cross and Gauja 2021). The reason for this can be found in the general trend characterising leadership election reform. Since it is marked by a unidirectional expansion of the selectorate, or "democratisation", a closer look at what drove these reforms often seems only warranted in terms of the gains sought by expanding the electorate rather than the actual prevalence of this goal among relevant actors (Kenig 2008, pp. 240-241; Cross and Blais 2012a, pp. 14-16; Pilet and Cross 2014, pp. 226-229; Kenig et al 2015a, pp. 32-34; Chiru et al 2015, pp. 32-33).

However, the respective research also shows that the formal trend towards selectorate expansion is often only a surface level development, qualified by the specific design of those rule changes (Cross and Blais 2012a, pp. 82-85 and 2012b, pp. 
128-129; Kenig 2008, p. 241, Kenig et al. 2015a, pp. 33-34). While some literature goes further by pointing out that the goal of "democratisation" is not universally shared by all elements of the parties, most of this criticism is drawn from general assumptions about institutional conservativeness and oligarchic tendencies of party elites in the tradition of Robert Michels (Cross and Blais 2012b, p. 128; Hazan and Rahat 2010, p. 34; Kenig 2008, pp. 240-241) rather than from the specific perspective of leadership election reform (with the UK specific research being an exception, Stark 1996; Heppell 2010a).

There is an inherent tension in the general results of both the British and internationally comparative analyses. Both assume that there are universal/uniform reform and/or electoral interests which are (at least partially) contradicted by a concurrent prominence of particularistic interests of intra-party actors. This is the issue where this article tries to address some of the shortcomings of the respective research. First, I assume that there is neither an exclusive nor necessarily prevalent goal in leadership election reform. Instead, reforms can be employed to both further the particularistic interest of specific actors or the more utilitarian interest of the party as a whole (Kenig et al 2015a, pp. 33-35; Hazan and Rahat 2010, pp. 97-103; Chiru et al 2015, p. 33).

Second, these two general goals inadvertently conflict to some degree. In the case of "democratisation" being the principle guiding reform efforts we should be able to observe a continuous and stringent increase of open-endedness as well as an empowerment of the common membership (Hazan and Rahat 2010, pp. 53-54; Bale and Webb 2014, pp. 27-29; LeDuc 2001, pp. 323-325; Kenig 2008, pp. 241-243; Kenig et al 2015a, pp. 24-29). Accordingly, such "democratisations" should become apparent in reforms that make it easier for individual candidates to run, increase the common membership's influence on the final outcome and lead to less lopsided voting results. Conversely, a high frequency of rule changes with diffuse or contradictory electoral outcomes should instead point to other reform reasons or motivations.

This has two potential reasons, outlined by Timothy Heppell (2010a, pp. 196-198). First, reforms could be far less comprehensive and impactful than they were initially presented or their outcome could have had unintended consequences leading to further modifications (Quinn 2018, pp. 480-481). Second, if reforms are the outcome of intra-party bargaining or power struggles between actors with vested interests, these actors should be tempted to limit the "democratising" effect of reforms (unless "democratisation" serves their own interests, Hazan and Rahat 2010, pp. 53-54). As long as none of them manage to secure a dominant position, other actors would have an interest in modifiying these changes once the general power distribution within the party shifts (Stark 1996, pp. 64-65, Cross and Blais 2012a, p. 85). Accordingly, largely pre-structured election outcomes as well as rule changes that only alter which actors wield more influence over the final results would instead indicate a prevalence of internal power struggles rather than a generally agreed process of "democratisation". While individual reform measures created by such power struggles might be compatible with those of true "democratisation" attempts under certain circumstances (for example, the broadening of the franchise can be supported to achieve both utilitarian or egoistic goals, Hazan and Rahat 2010, pp. 97-103), their overall outcome and long-term development should be far more 
erratic and inconsistent. Therefore, the consistency of outcomes should give us a clear impression whether reforms were rather guided by a comprehensive long-term "democratisation" project or continuous factional power struggles.

This has consequences for another aspect in which this article will try to go beyond the typical approaches to the subject. Instead of understanding reform willingness as a static concept that divides two vaguely defined groups with fixed interests, I will consider it as a dynamic concept that can be utilised or rejected by various actors depending on their situational and strategic interests, as suggested by Heppell (2010a, pp. 197-206). As a consequence, this article seeks to identify different strategic actors within the Labour party that have a vested interest in the issue and then tries to analyse reform benefits or power losses along these specific groups, instead of operating with rather amorphous and ill-defined group labels like "reformers" or "conservatives".

In terms of how the article seeks to analyse the impact of electoral reforms and thereby the prevalence of different reform goals, the aim is to achieve this by comparing the actual outcomes of leadership elections since 2007 with nominal outcomes based on the rule sets adopted later on (or by assuming the continued use of older rule sets). This procedure seems particularly sensible in light of Keir Starmer's attempt to roll back the current "one member, one vote" (OMOV) system and re-establish the pre-2014 electoral college. It is also to some degree inspired by Stark's (1996, pp. 9 and 131-138) contrafactual approach, but still quite different from it. While Stark estimates institutional impact exclusively by the likelihood of a different person getting elected under modified rules, I (predominantly) focus on the gradual differences in results. Depending on how much the results would have changed under different electoral settings and which strategic actors profited from the changes in question it should be possible to assess whether the reforms reflected a "democratisation" of leadership elections or power struggles among these actors. In order to replicate the structural division between electoral phases and the differences in adequate measurements of "democratisation", I will split my analysis into the (fairly) independent phases of nominations and final ballots (Hazan and Rahat 2010 , pp. 38). The specific procedures for each phase and strategic actor are outlined in further detail in the empirical section.

\section{Strategic actors within the Labour party}

In order to identify strategic actors within parties Katz and Mair's (1993) seminal work on the "three faces of party organisation" is still an instructive starting point. The authors argue that parties' political decisions are shaped by conflicting interests of the party central office, the party in public office and the party on the ground. Since the party in public office is primarily interested in getting re-elected, it should strive for the selection of leaders that excel at what Dorey and Denham (2016, pp. 260-261) describe, following Stark's second priority goal, as "electability". Being able to appeal to members of the general public conflicts, at least to a certain degree, with the interests of activists who usually want to see the promotion of party identity and ideological commitments 
(Katz and Mair 1993, p. 598). Conversely, the party central office takes a position between these two faces since it is typically chosen to different degrees by them. Depending on its independence from both, it will try to increase the size of its bureaucracy and influence on the party's internal decisions as well as the financial resources at its disposal (Katz and Mair 1993, pp. 599-600).

Despite the framework's usefulness, I need to further modify it for three reasons. The first problem lies in the strong and unique institutionalisation of the trade unions in Labour's organisational structure. Currently the unions are represented in the National Executive Committee (NEC) and the National Policy Forum (NPF) as well as the party conference, and their members can vote in leadership elections. Besides this formal integration, the largest unions have significant informal access to representatives of the party central office and the party in public office due to their large financial assets and still respectable pool of potential supporters (Ludlam and Taylor 2003, pp. 731-735). Accordingly, every study of Labour's internal structure has to recognise the unions as an autonomous entity that will try to influence the party's general course and internal politics.

The second major issue lies in the central office's lack of independence. This face is usually associated with the NEC, the NPF, the party leader, his or her personal staff and the general secretary. Among it, the NEC and NPF fulfil task sharing, although the NEC holds the more powerful role, with the NPF being responsible for developing policies while the NEC manages the party's administrative work. Since the New Labour era NEC membership has fluctuated between 32 and 40 members, with the unions currently selecting 13, the Constituency Labour Parties (CLPs) nine and different MPs holding eight seats. The rest are awarded to various special interest groups (Labour party 2021; Ludlam and Taylor 2003, pp. 731). Since the NEC's various sections are selected by different electorates representing other strategic actors it is almost impossible for it to develop a "corporate identity" or autonomous strategic interest (Katz and Mair 1993 p. 599). Therefore, the NEC clearly lacks sufficient independence to be considered an autonomous player and can be disregarded here.

Finally, there is the problem of internal cohesion among the different actors outlined above. Naturally each of them is composed of various ideological factions that will act in alliance with factions of other sections ideologically close to them rather than with opposed factions of their own section. Therefore, the central challenge, when looking into questions of intra-party power distribution, is whether one should focus on these specific factions or still concentrate on the party's structural "faces" (Katz and Mair 1993, p. 594). To deal with this problem I employ a synthesis of both approaches. In structural decisions, like leadership elections, the general interest of each section should be to increase its own influence while containing that of other segments. However, since no section is exclusively made up of a single ideological faction, the respective minorities should be more interested in strengthening other sections where the majority is ideologically closer to them. This should especially be the case if a minority sees no viable path of becoming the majority among its own section. 


\section{Labour leadership election reform in the 2010 s}

Before looking into the impact of Labour's leadership election reforms, it is necessary to briefly outline the actual rule changes of the 2010s. The phase of "modern" leadership elections in the Labour party began with John Smith's 1993 reform. While it still preserved the existing electoral college system (in which, since 1993, the vote of MPs, party and trade union members separately accounted for one third of the overall vote), it abolished the old delegate principle by giving the right to vote to the respective sections' members. In addition, the nomination threshold a candidate had to reach among the PLP to get on the final ballot was lowered from 20 to 12.5 per cent (Quinn 2012, p. 62, Dorey and Denham 2016, pp. 262-263). Further major reforms steps since the New Labour era took place as a result of the 2014 Collins review as well as during the 2018 and 2021 party conferences.

The most important of these was the Collins report of 2014. This inquiry had been initiated on behest of Labour leader Ed Miliband after media reports of potential vote rigging for the Falkirk constituency nomination surfaced. During the selection process, expelled Falkirk MP Eric Joyce (2013) accused the local CLP chairman Stephen Deans of secretly signing up Unite union members in order to get a specific candidate, Karie Murphy (Jeremy Corbyn's later chief of staff), selected. Conservative news outlets presented this as proof of widespread corruption and manipulation of the party by the unions. These attacks were directly aimed at Miliband, who had been continuously portrayed as a puppet of union bosses because his election was based in his advantage in the union section of the vote (Quinn 2016, p. 762). In order to counter criticism Miliband announced the party would review its leadership election process, specifically targeting the unions' role in it (Dorey and Denham 2016, pp. 265-266). The resulting inquiry, led by Lord Collins of Highbury, made a number of recommendations that were adopted in 2014 (Collins 2014, pp. 7-8), including:

(1) Abolition of the college system: Instead all votes would be counted together requiring candidates to reach a simple majority determined by a ranked preference vote.

(2) Abolition of the old PLP/EPLP section: MPs and MEPs would now vote together with common members.

(3) Abolition of the right to vote multiple times (by being, for example, an affiliated union and party member) and replacement with a true OMOV system.

(4) Introduction of individual and personal registrations for union and socialist society members as "affiliated members", instead of the older, centralised bloc registration by union executives.

(5) Increase of the PLP nomination threshold from 12.5 to 15 per cent.

(6) Although only a minor suggestion, the special conference decided to create a new third electoral section, "registered supporters". People who were neither party members nor eligible for affiliated member status would be able to register exclusively for the leadership election for a reduced membership fee. The NEC would set specific registration deadlines and fees for each election. 
Due to the election of Jeremy Corbyn as Labour leader, this procedure only remained unchanged for a short time. With his attempted removal and subsequent re-election in 2016, the internal power struggle between the hard left and the centrist PLP majority soon found its way into the issue of leadership election reform. As a consequence of Corbyn's re-election, his PLP supporters and the grassroots organisation Momentum pushed for a stronger representation of "Corbynistas" in the party bureaucracy as well as among parliamentary candidates. Despite the growing influx of hard left MPs during the 2017 snap election they remained a clear minority among the PLP and were concerned about a future succession to Corbyn because of the high nomination threshold. Therefore, CLP delegates (most of whom were on the left of the party and supporters of Corbyn's leadership) had already pushed the 2017 party conference to lower the threshold to ten per cent and subsequently focussed on further lowering it to five per cent as well as on introducing mandatory reselections of MPs and the possibility of local chapters to recall them (Quinn 2018, pp. 479-480). While the majority of larger unions strongly supported Corbyn and were not fundamentally opposed to such changes, union representatives were still dissatisfied with their diminishing role in the election process. They also felt threatened by Momentum's attempts to take control of almost every organisational aspect of the party (Seyd 2020, pp. 12-13).

In order to defuse a potential conflict between the different sections of the party's left, the union leaderships proposed a byzantine compromise arrangement. While the final vote should remain untouched, the nomination process was to be heavily amended. Candidates would still have to collect the endorsements of ten per cent of the PLP (Labour Party 2020a: Clause II, 2 B i), but a second nomination round was to be introduced. Here candidates would either need the support of organisations representing five per cent of all members of the affiliated section or five per cent of all CLPs. In addition, the first nomination path would require the support of at least two different unions and three unions and/or socialist societies overall. Only candidates passing both consecutive nomination rounds would be included in the final vote (Labour Party 2020a: Clause II, 2 B a and b). This compromise was furiously rejected by the vast majority of left-wing CLP delegates, who regarded it as a move to increase union influence at the expense of ordinary party members. As a consequence, union representatives had to rely on the help of moderate delegates to secure a majority at the conference vote, further deteriorating the relationship between them and party activists (Elgot and Syal 2018).

However, just three years later, on September 21st 2021, Keir Starmer took his party by surprise when he announced he would ask the party conference, starting later that week, to re-establish the pre-2014 college system. Under his proposal the 2018 nomination stage changes would be kept in place, but the final ballot should once again be conducted among three equally weighted sections of MPs, party members and affiliates. Starmer deliberately tried to woo the major unions to support his proposal which, however, was strongly rejected by most of them. As a consequence, he dropped his initial plan, but replaced it with the abolishment of the registered supporter category and raising the PLP nomination threshold to 25 per cent (Elgot and Stuart 2021). After intense negotiations with union representatives and the NEC, the leadership pressed ahead with its modified reform plan, but lowered 
the intended threshold to 20 per cent (the same margin used from 1988 to 1993). In the end, the conference very narrowly approved Starmer's proposal thanks to Unison's last-minute decision to actively support it.

What should have become clear in this chapter is that the electoral reforms of the 2010s were framed around the general discussion of "empowering" common party members, but also took place against the background of intense conflicts between different internal actors. Therefore, the main question, and subject of the next chapter, is which phenomena had a greater impact on the character of the resulting reforms.

\section{Leadership elections from 2007 to 2020}

In this section I will first take a brief look at the theoretical implications of the aforementioned reforms and then investigate their effects on the outcome of leadership elections. In accordance with my earlier reasoning, I will divide my observations along the two independent dimensions of nominations and actual voting (Hazan and Rahat 2010, p. 38), as well as along the party's different strategic sections.

Starting with the PLP section during the nomination stage, we should expect a clear power decline of the parliamentary party due to the initial reduction of the nomination threshold (Quinn 2004, pp. 336-339). Considering that the "democratisation" of the nomination stage is typically measured by the number of candidates reaching the final ballot (Hazan and Rahat 2010, pp. 53-54, Kenig et al 2015a, p. 24 and 2015b, p. 58), it is instructive to compare the number of announced candidacies with the number of those who would have reached the final vote under the various thresholds employed by the party.

Using the last employed threshold of ten per cent we can see that all four candidates who originally failed the first nomination round, Clive Lewis (2020), Mary Creagh (2015), Michael Meacher (2007) and John McDonnell (2007 and 2010) (disregarding Chuka Umunna's three day bid in 2015), would not have passed this threshold either. Differences only start to show once it is lowered to five per cent (the margin until 1988, Quinn 2018, p. 479). Accordingly, McDonnell would have reached the final round in 2010 and either he or Michael Meacher in 2007. Conversely, we can also look at how the contender field would have changed under the highest threshold employed so far. Under the new 20 per cent margin, elections would have started to turn into coronations. In 2020, only Keir Starmer reached it, while 2010 (Ed and David Miliband) and 2015 (Andy Burnham and Yvette Cooper) would have been limited two-way contests. Further, with Keir Starmer's initial 25 per cent proposal in place, Ed Miliband would have also missed the threshold, while Yvette Cooper barely crossed it with a single excess vote. Still, taking the now fairly common practice of Leihstimmen (vote lending), ${ }^{1}$ by MPs to candidates they do not

\footnotetext{
${ }^{1}$ Leihstimmen is a concept of strategic voting typically associated with voting preference hierarchy in German elections. It describes situations in which parties, politicians or voters prioritise strategic considerations (for example preferences for a specific government coalition) over expressive voting and therefore lend their vote (or encourage others to do so) to parties, voters would not consider as their first choice in terms of policy preferences.
} 
actually support, into account, it could have been possible, although unlikely, for another candidate to reach the threshold in these cases. The importance of this practice in diversifying nominations becomes clear once we consider that, of the 16 candidates who actually passed the threshold, Abbott, Balls, Burnham (2010), Corbyn (2010), Phillips and Thornberry (plus potentially Kendall) had to rely on vote lending to some degree.

In summary, the party in public office yielded most of its power concerning the nomination stage (at least until 2021). Not only was the threshold significantly lowered, the PLP also voluntarily gave away much of its remaining potential to block fringe candidates due to the now common Leihstimmen practice. However, Leihstimmen are usually only given to people who are seen as having no chances of winning. The public regret of many of Jeremy Corbyn's 2015 nominators underlines that the purpose of such "help" is not to enhance competition but to "simulate" democracy, in order to placate the various ideological factions by showing that they are not technically excluded from participation (Dorey and Denham 2016, p. 270, Crines et al 2018, pp. 364-365).

From a theoretical perspective the decline of influence of the party in public office on the ballot dimension should be the most pronounced of all trends. Until 2014 the PLP controlled one third of the vote and should have easily been able to tip the balance in close contests (Quinn 2004, p. 345, Dorey and Denham 2016, p. 264). This fixed electoral weight of different voting sections irrespective of their numerical size is also the main difference between electoral colleges and OMOV systems (Hazan and Rahat 2010, pp. 35-38). Accordingly, to estimate the impact of the PLP it is instructive to look at how the outcomes of the first election rounds would have changed if the old college system was still in place. To do this I assigned the results of the PLP/EPLP, the party members and the affiliated members sections a weight of one third of the overall vote, as was done under the college system, and recalculated the outcome of the post-2010 elections (the procedure was reversed for 2010 to create a nominal outcome assuming an OMOV system). Since the section of registered supporters did not exist before 2014, I calculated two different scenarios, one assuming this segment was never created by completely excluding its vote, and one counting it among the affiliated members section. Table 1 outlines each candidate's nominal relative vote compared to their actual result.

The most striking observations are that Owen Smith would have easily carried the 2016 election, while Jeremy Corbyn would have clearly missed a first-round victory in 2015 under the first scenario and narrowly under the second one. However, we can also see that the serious effects of the college system would have been limited to the 2016 two-person run-off. In 2020 there would have been almost no effect, with Keir Starmer performing less than one point better or worse depending on the scenario. The same is true to a lower degree for 2010 which would have seen David Miliband performing four points better and his brother Ed receiving about three points less (while the younger Miliband would have still beaten his brother by almost nine points in the fourth round) under today's OMOV principle.

These results somehow qualify the extent of PLP power decline. Only the contagious 2016 election would have clearly been swayed in a different direction had the PLP retained its disproportional influence. While there would have been a small 


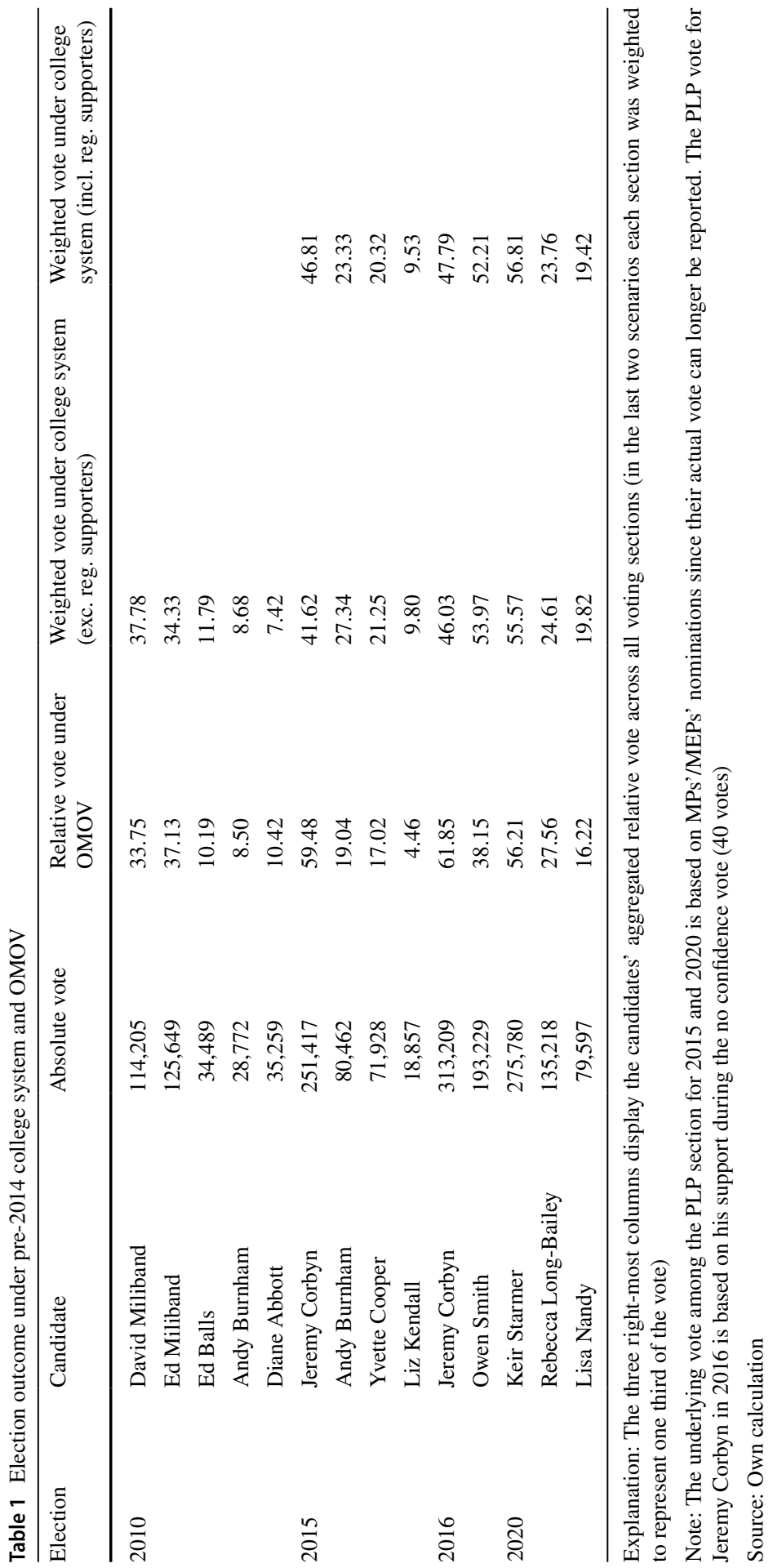

我 
Table 2 Union endorsements

\begin{tabular}{lllll}
\hline Union & 2010 & 2015 & 2016 & 2020 \\
\hline Unite & Ed Miliband & Jeremy Corbyn & Jeremy Corbyn & Rebecca Long-Bailey \\
Unison & Ed Miliband & Jeremy Corbyn & Jeremy Corbyn & Keir Starmer \\
Usdaw & David Miliband & Andy Burnham & Owen Smith & Keir Starmer \\
GMB & Ed Miliband & No endorsement & Owen Smith & Lisa Nandy \\
CWU & Ed Balls & Jeremy Corbyn & Jeremy Corbyn & Rebecca Long-Bailey \\
ASLEF & Diane Abbott & Jeremy Corbyn & Jeremy Corbyn & Rebecca Long-Bailey \\
BFAWU & No endorsement & Jeremy Corbyn & Jeremy Corbyn & Rebecca Long-Bailey \\
Community & David Miliband & Yvette Cooper & Owen Smith & Keir Starmer \\
Musicians Union & No endorsement & Andy Burnham & Owen Smith & Keir Starmer \\
NUM & No endorsement & Yvette Cooper & No endorsement & Lisa Nandy \\
TSSA & Diane Abbott & Jeremy Corbyn & Jeremy Corbyn & Keir Starmer \\
UCATT & Ed Miliband & Andy Burnham & Jeremy Corbyn & Merged with Unite \\
FBU & & & Jeremy Corbyn & Rebecca Long-Bailey \\
BECTU & No endorsement & No endorsement & No endorsement & Merged with Pros- \\
& & & & pect \\
\hline
\end{tabular}

Note: FBU reaffiliated with Labour after the election of Jeremy Corbyn as party leader in 2015. Due to its merger with Prospect BECTU disaffiliated from the party in 2017. In September 2021 BFAWU announced that it would disaffiliate from Labour

chance of Burnham beating Corbyn in a tight hypothetical third round in 2015 (Quinn 2016, pp. 767-768), neither the 2010, 2015 or 2020 outcome would have significantly changed under a different counting system.

For the trade unions, the theoretical situation looks more mixed. While we should expect a massive decline concerning their influence on the final ballot, due to the abolition of centralised registrations and the guaranteed voting weight under the college system, there should be small improvements concerning the nomination stage thanks to the introduction of the second nomination round (Dorey and Denham 2016, pp. 267-268 and 2011, pp. 292-293). Again, it is instructive to judge the impact of the latter reform measure by looking at how many candidates would have passed today's second round based on the unions' endorsement behaviour in the past.

Currently there are 12 affiliated unions and 20 socialist societies. This would theoretically allow a maximum of six candidates to pass the threshold. Yet, due to the highly skewed membership structure this number is limited to five, with the "big five" (Unite, Unison, Usdaw, GMB, CWU) holding around 96 per cent of the union membership. ${ }^{2}$ This gives considerable power to the leaderships of these unions since nominations are mostly decided by their executive councils. Looking closer at their recommendation practice we can see that the "big five" never endorsed more than

\footnotetext{
2 Union membership was around 2,000,000 in early 2020, while socialist society membership was only around 26,000 (Sparrow 2020).
} 
three different candidates (Table 2), strongly limiting the openness of the nomination stage. Accordingly, while five candidates passed the first nomination round in 2010 , four in 2015 , and five in 2020, the new rule would have/has limited candidacies to three, two and three, respectively.

While there are various approaches to estimating the unions' impact on the final vote, the inadequate availability of data on individual union members' voting behaviour severely limits the viability of most of them. First of all, union leaders obviously have no direct control over how their members vote after the block vote was abolished. In order to measure their "influence" it is therefore sensible to look at how many members actually follow their leaderships' advice. This can be measured by the rate of coherent voting (members voting for the candidate endorsed by their union). According to Jobson and Wickham-Jones (2011, p. 335) and Pemberton and Wickham-Jones (2013, p. 724) the average coherency rate in 2010 was 49.3 per cent. While there was a significant spread of coherent voting, depending on the individual union (ranging from 30.5 to 66.9 per cent), deviations were largely confined to smaller unions and those supporting David Miliband. Coupled with an abysmal turnout of just nine per cent, only about 4.5 per cent of the whole union membership voted for the candidate endorsed by their respective leadership.

The next step is to estimate how important such coherent voting was to an individual candidate's result in the affiliated members section. Unfortunately, the necessary data are only available for the 2010 election (Jobson and Wickham-Jones 2011, p. 335, Dorey and Denham 2011, p. 309). However, if we assume that the determinants of union members' voting behaviour have been fairly stable, the coherent voting rate should have remained at roughly the same level in subsequent elections. Therefore, I used the individual unions' rates of coherent voting in 2010 as a baseline for the following calculations. First, I tried to establish how many votes each candidate would have been expected to receive from coherent voting alone. Based on the 2010 numbers, I calculated an endorsement weight for each individual union which reflects the proportion of that union's coherent voters in comparison to all voters in the affiliated section. For example, based on its members' turnout and rate of coherent voting, Unite's endorsement of Ed Miliband was theoretically worth 22.5 per cent of the whole affiliated section's vote. I then added up the individual endorsements to calculate each candidate's overall theoretical endorsement weight (Table 3, third column), meaning that the various unions supporting Ed Miliband should have guaranteed him 36.7 per cent of the affiliated section's vote from coherent voting alone, or an absolute number of 77,690 votes (fourth column). This number was then contrasted with the candidate's actual union support in the first round (fifth column) for which Miliband held 87,585 first preferences. Finally, the amount of the candidate's actual vote in the affiliated section that could be explained by the expected coherent voting is displayed in the sixth column, which in Miliband's case was a rate of 88.7 per cent.

This explanation rate should give us an impression of the importance of union nominations and allow for some general statements about their influence on leadership elections. Quite obviously, the higher the explanation rate, the more important the unions' nominations were for that candidate, and the better a candidate with a high endorsement weight performed, the greater was the general influence of the 
Table 3 Value of union endorsements and nominations

\begin{tabular}{|c|c|c|c|c|c|c|}
\hline & & $\begin{array}{l}\text { Endorse- } \\
\text { ments } \\
\text { numbers }\end{array}$ & $\begin{array}{l}\text { Endorse- } \\
\text { ment } \\
\text { weight }\end{array}$ & $\begin{array}{l}\text { Predicted } \\
\text { coherent } \\
\text { vote }\end{array}$ & $\begin{array}{l}\text { Actual affili- } \\
\text { ated members } \\
\text { vote }\end{array}$ & $\begin{array}{l}\text { Percentage } \\
\text { explained by } \\
\text { coherent vote }\end{array}$ \\
\hline \multirow[t]{4}{*}{2010} & Diane Abbott & 2 & 1.27 & 2,689 & 25,938 & 10.37 \\
\hline & Ed Balls & 1 & 3.36 & 7,101 & 21,618 & 32.85 \\
\hline & David Miliband & 2 & 4.52 & 9,556 & 58,189 & 16.42 \\
\hline & Ed Miliband & 4 & 36.78 & 77,690 & 87,585 & 88.70 \\
\hline \multirow[t]{3}{*}{2015} & Yvette Cooper & 2 & 0.61 & 438 & 9,043 & 4.84 \\
\hline & Andy Burnham & 2 & 5.08 & 3,636 & 18,604 & 19.54 \\
\hline & Jeremy Corbyn & 6 & 31.66 & 22,653 & 41,217 & 54.96 \\
\hline \multirow[t]{2}{*}{2016} & Owen Smith & 4 & 13.11 & 13,072 & 39,670 & 32.95 \\
\hline & Jeremy Corbyn & 8 & 32.83 & 32,748 & 60,075 & 54.51 \\
\hline \multirow[t]{3}{*}{2020} & Lisa Nandy & 2 & 8.58 & 6,528 & 18,681 & 34.95 \\
\hline & Rebecca Long-Bailey & 5 & 27.84 & 21,175 & 16,970 & 124.78 \\
\hline & Keir Starmer & 5 & 9.52 & 7,240 & 40,417 & 17.91 \\
\hline
\end{tabular}

Explanation: The endorsement weight describes the percentage of the overall union vote a candidate would be expected to receive based on coherent voting. The predicted vote is the absolute vote corresponding to the endorsement weight. The explained percentage is the proportion of the candidate's actual absolute vote that is explained by the predicted absolute vote. Candidates not receiving any union endorsements have been omitted

Source: Own calculation based on the numbers by Jobson and Wickham-Jones (2011) and Pemberton and Wickham-Jones (2013)

unions on that election. In addition, attention should be paid to the relationship of the endorsement weight and the explained percentage. The higher the latter compared to the former, the greater the importance of unions' endorsements was for that candidate, while closer numbers indicate a greater independence of a candidate's support, unless the endorsement weight itself is very high. To return once more to the example of Ed Miliband this means the unions were highly influential in 2010, since the younger Miliband, who had a very high endorsement weight, came out on top of the contest and had a very high explanation rate, indicating that the vast majority of his support came from coherent voting.

Looking at the results, we can see that, in general, the predicted percentage increases with the number and theoretical weight of endorsements. The numbers also show that union endorsements still hold considerable value, especially for candidates on the left and those receiving the nominations of the "big five". For all three more left-leaning frontrunners (Ed Miliband, Corbyn, Long-Bailey), endorsements explain at least 50 per cent of their vote, while the explanatory values for Abbot and Balls (the more left-wing underdogs) ${ }^{3}$ were almost ten times higher than

\footnotetext{
${ }^{3}$ Balls' ideological placement is debatable. However, as Dorey and Denham (2011) and Pemberton and Wickham-Jones (2013) point out, concerning his positions and public perception during the leadership contest, as well as the voting behaviour of his supporters, he was ideologically very close to Ed Miliband and is therefore considered "left-wing" for the purpose of this study.
} 
the theoretical weights of their nominations. Conversely, moderate or "establishment" candidates (specifically David Miliband, Cooper, Smith and Starmer) display considerably lower endorsement weights and predictions rates. This means centrist candidates do not have to rely on endorsements because they will receive the bulk of their votes from union members not following the advice of their leaderships.

The final issue to consider is the group of common party members and activists. Theoretically, the introduction of the second nomination round should have had the same effect on their influence as it had for the unions due to the comparable design of both procedures. Despite this, the CLP nomination route is marred with practical difficulties, making it fairly unattractive for candidates. Therefore, I will outline various reasons that counter-indicate this route's potential for broadening the field of contenders, rather than try to estimate its impact through CLPs' previous endorsement behaviour.

First, although unions and CLPs nominate during the same time period, the unions' faster pace effectively pushes CLPs into a third nomination stage (in 2020 over a third of all CLPs only nominated during the last seven days; for this sequencing issue see Quinn 2004, pp. 340-341).

Second, almost no contender has the resources and ground game necessary to actively pursue this path. All campaigns heavily rely on voluntary work and have limited financial resources (Jobson and Wickham-Jones 2011, p. 328), but even more importantly, the party does not provide access to its membership lists until candidates have reached the final ballot (Labour Party 2020b, pp. 1-2), making direct contact with members at this crucial stage very difficult.

Third, with basically no possibility of direct contact, except for a few regional hustings, there is a strong tendency of CLPs to endorse high-profile candidates, which often tend to be "establishment" frontrunners. Accordingly, Keir Starmer alone received 58 per cent of all CLP nominations in 2020 (Johnston 2020, p. 12), while in 2016 Jeremy Corbyn secured more than five times as many endorsements as the almost unknown Owen Smith. In 2010 Ed and David Miliband had largely the same number of endorsements (151 to 165), but together they accumulated 80 per cent of all recommendations. Only 2015 displayed a fairly balanced distribution between the top three candidates, with Cooper and Burnham securing around 28 per cent and Corbyn receiving 39 per cent (Quinn 2016, p. 763). Accordingly, candidates who are not already frontrunners have to secure a far higher percentage of the actually "available" CLP nominations than five per cent.

Fourth, the union nomination route is just too tempting for candidates to specifically focus on the CLP option. Taking the aforementioned factors together, it is far easier to persuade the board room of a single large union and two very specialised interest groups/small unions than to convince larger groups of local party members across the whole country, about whose political leanings the candidates have little knowledge. ${ }^{4}$

\footnotetext{
4 There are two potential exceptions to these issues: having the support of a strong pressure group lobbying on behalf of a candidate (like Momentum) or the candidacy of several high-profile party figures.
} 
Table 4 Turnout figures by section

\begin{tabular}{lllllll}
\hline & PLP/EPLP & Members & Affiliated members & $\begin{array}{l}\text { Registered } \\
\text { supporters }\end{array}$ & All sections \\
\hline 2010 & Absolute votes & 266 & 126,874 & 211,234 & & 338,374 \\
& Eligible voters & 269 & 177,558 & $2,747,030$ & & $2,924,857$ \\
& Percentage of the vote & 0.08 & 37.50 & 62.43 & & 100 \\
& Turnout & 98.88 & 71.45 & 7.69 & & 11.57 \\
2015 & Absolute votes & 204 & 245,316 & 71,546 & 105,598 & 422,664 \\
& Eligible voters & 233 & 292,740 & 148,182 & 112,799 & 553,954 \\
& Percentage of the vote & 0.05 & 58.09 & 16.93 & 24.98 & 100 \\
& Turnout & 87.55 & 83.80 & 48.28 & 93.62 & 76.30 \\
2016 & Absolute votes & 212 & 284,964 & 99,745 & 121,517 & 506,438 \\
& Eligible voters & 251 & 343,249 & 168,000 & 129,000 & 654,006 \\
& Percentage of the vote & 0.04 & 56.31 & 19.70 & 23.99 & 100 \\
& Turnout & 84.46 & 83.02 & 59.37 & 94.20 & 77.44 \\
2020 & Absolute votes & 153 & 401,368 & 76,068 & 13,006 & 490,595 \\
Eligible voters & 212 & 552,623 & 217,690 & 13,626 & 784,151 \\
Percentage of the vote & 0.03 & 81.84 & 15.51 & 2.65 & 100 \\
Turnout & 72.17 & 72.63 & 34.94 & 95.45 & 62.56 \\
\hline
\end{tabular}

Note: The numbers for the PLP/EPLP section are based on MPs' and MEPs' nominations, not their actual voting behaviour. The numbers of eligible voters for 2016 are inconsistent because the NEC only reported them at the ballot send-out deadline, but had to overturn a number of exclusions before the actual vote due to ongoing court challenges

Source: Own calculation based on the numbers by Johnston (2020), Sparrow (2016), Labourlist (2015), Dorey and Denham (2011), and Jobson and Wickham-Jones (2011)

This leads us to the evaluation of party members' influence on the final vote. Theoretically, we should expect a significant increase of their voting power due to the abolition of the college system itself, and more specifically because of the dissolution of the PLP section (Dorey and Denham 2016, p. 267; Quinn 2016, p. 768). Since a standard analysis of members' voting behaviour would hardly tell us anything about their influence, compared to other strategic actors, it seems logical to employ an approach more focussed on the strategic electoral weight of this section. Under the college system, members' electoral weight was fixed at a third, but afterwards their voting power solely depended on the turnout and numerical size of the various sections. Accordingly, it should be instructive to look at their proportion of the overall vote and compare it to the fixed weight under the college system (Table 4). However, since the general membership of the three voting sections, as well as their respective turnouts, are dynamic, we have to account for these developments because they might modify the members section's electoral weight, but are not related to election rule changes (Table 5).

If the abolition of the college system did not lead to party members holding significantly more than a third of the overall vote, then the supposed 
Table 5 Relative vote by section under different participation scenarios

\begin{tabular}{lllllr}
\hline & & PLP/EPLP & Members & $\begin{array}{l}\text { Affiliated } \\
\text { members }\end{array}$ & $\begin{array}{r}\text { Registered } \\
\text { supporters }\end{array}$ \\
\hline Scenario 1: & 2015 & 0.04 & 43.62 & 37.56 & 18.78 \\
Stable union vote & 2016 & 0.03 & 46.12 & 34.18 & 19.67 \\
& 2020 & 0.02 & 64.14 & 33.76 & 2.08 \\
Scenario 2: & 2015 & 0.06 & 45.62 & 21.94 & 32.38 \\
Stable party membership* & 2016 & 0.06 & 39.96 & 27.04 & 32.94 \\
& 2020 & 0.07 & 59.11 & 34.86 & 5.96 \\
Scenario 3: & 2015 & 0.04 & 31.94 & 45.35 & 22.67 \\
Stable membership + union vote* & 2016 & 0.04 & 30.69 & 43.97 & 25.30 \\
& 2020 & 0.04 & 36.50 & 59.78 & 3.68 \\
\hline
\end{tabular}

Explanation: The displayed numbers represent the proportion of the respective section's vote of the overall vote. Scenario 1 assumes 2010's absolute number of votes in the affiliated section for all subsequent elections. Scenario 2's numbers assume the same absolute number of eligible party members as in 2010 for later elections. Scenario 3 combines the assumptions of the two previous scenarios

* Under these scenarios the absolute vote in the members section is still weighted by the actual turnout leading to $148,794,147,408$ and 128,960 votes in 2015, 2016 and 2020, respectively

Source: Own calculation

"democratisation" of leadership elections was obviously a ruse. If, however, there has been a notable increase, we must check whether it is attributable to changes in the various sections' memberships and turnouts (thereby pointing to situational explanations) or to the structural changes created by the introduction of OMOV.

In order to do so I calculated three hypothetical scenarios accounting for the most important situational factors. Since the Collins review ended the unions' ability to register their members en bloc, and thereby made stronger fluctuations in the registration rate and turnout more likely, the first scenario assumes that the absolute union vote remained at the 2010 level in later elections. The second scenario tries to cancel out the prolonged surge of party members that took place since the 2015 leadership election and instead assumes a stability of the 2010 level, while the third scenario combines the premises of the previous two.

Looking at Table 4 we can see that, surprisingly, the one third assigned to members under the college system fairly accurately reflected their initial strength. Accordingly, members only accounted for 37.5 per cent of all votes in 2010 . This changed considerably afterwards with numbers rising from 58.1 and 56.3 to 81.8 per cent over the next elections. While this is a significant increase it has to be qualified by situational factors. First, the substantial drop in registrations and turnout in the affiliated section accounts for almost half the change. Assuming a stable number of union votes (Table 5, Scenario 1), the members section would have only seen moderate weight increases to 43.6 and 46.1 per cent in 2015 and 2016. Only in 2020 would party members have accounted for about two thirds of the vote. Since these developments of the union vote were facilitated by the switch to individual voter registration rather than the abolition of the electoral 
college, it is the result of a measure that was not even aimed at increasing party members' influence and therefore more of an unintended by-product.

Second, the other half of the increase is explained by the unprecedented rise in party membership. The absolute abstention numbers among it were almost the same in 2010 and 2015 (around 50,000), while they rose only slightly in $2016(58,000)$. However, overall membership increased by over 120,000 until 2015 and another 50,000 until 2016. Under stable membership figures (Scenario 2) the section's weight would have only moderately risen to 45.6 per cent in 2015 and 40 per cent in 2016. Even the considerable change in 2020 has to be somewhat qualified by these developments. While absolute union registrations rose close to the 2010 turnout, the section's actual turnout fell to lower levels than before. Simultaneously, the number of registered supporters collapsed by 90 per cent. These developments more than compensated for the far lower turnout among party members. In the end, under stable membership figures, the members section would have constituted 59.1 per cent of the overall vote in 2020, still over 21 per cent lower than under the actual results.

Finally, I ran a third scenario assuming both a stable party membership and a durable union vote. Unsurprisingly, under such a configuration the membership's power would have been around the same as under the college system for every election, irrespective of the developments among registered supporters.

What does this tell us about the change of ordinary members' influence? First, it tells us that the mantra of "democratisation" often employed by various actors during reform processes had a limited impact on members' actual influence. The nomination power has (so far) been largely insignificant since it tends to mostly benefit candidates that do not need the help of ordinary members (Kenig 2008, p. 246; Kenig et al 2015b, p. 54). Second, we can conclude that the shifts in the voting power of the members section have little to do with the abolition of the fixed college ratio or, conversely, that the college system reflected the membership's true electoral weight at the time. The switch to the OMOV system would have been of almost no consequence in this regard without the introduction of the individual registration requirement for union members (which had no imperative connection to it) and the unprecedented rise in party membership since 2010 (which seemed to be closer connected to Jeremy Corbyn's candidacy and election than increased membership benefits resulting from party reforms).

\section{Conclusion: A true "democratisation" or just a struggle for power?}

Returning to the central research question of this article, to what degree did the reforms to leadership selection reflect an actual "democratisation" or "just" a common power struggle within the Labour party?

Concerning the final ballot, the overall trend was one of "democratisation" in the sense that common party members theoretically gained significantly more influence. However, once we looked at how these changes operated in political reality the implied "empowerment" proved to be far less substantial than initially assumed (Hazan and Rahat 2010, p. 54; Bale and Webb 2014, pp. 27-29). Without the strong membership surge and the parallel fall in union turnout, members would 
still have only slightly more meaningful influence on election outcomes than under the electoral college. Still, the power gained by ordinary members came largely at the expense of the party in public office, which relinquished all its influence over the final ballot (Dorey and Denham 2016, p. 267; Quinn 2016, p. 768). But even the initial influence of party elites proved rather mediocre since they did not deviate strongly enough in their voting behaviour from the rest of the electorate, except in the final ballot round and in the case of a clear outsider reaching it. Finally, the unions were dealt a mixed hand. While their formal influence dropped significantly due to the end of the college system and the considerable fall in union member turnout, it seems that they at least managed to maintain their sway over those union members still turning out to vote, although they clearly failed to exert this influence in the latest election. Specifically for candidates on the left of the party, the endorsement of the "big five" still holds significant value, especially once we take the unions' new role in the nomination process into account (Quinn 2004, pp. 340-341; Jobson and Wickham-Jones 2011, pp. 337-338).

Concerning the nomination stage, we could also see improvements for common members, but once again these proved to be rather cosmetic than substantial. The CLP nomination right had no impact in 2020 (except for the deputy leadership election), and there are weighty reasons indicating that it will be unlikely to enhance the field of candidates in the future. Looking at the influence the party in public office has on nominations, we could see that initial changes to the threshold had little impact. Despite the notable decrease, it was still high enough to prevent fringe candidates from reaching the next round (Quinn 2018, pp. 478-480). Instead, the practice of Leihstimmen proved far more crucial than the formal threshold. While this practice seems to contradict the idea of PLP nominations acting as a tool of control by the party in public office, it has to be noted that, so far, nominations have been almost exclusively lent to candidates with (supposedly) no chance of winning (Dorey and Denham 2016, pp. 270). The re-establishment of the 20 percent threshold will make this practice even more crucial in future contests since it is now so high that almost all candidacies (except for one frontrunner) will have to rely on Leihstimmen to some degree. For the unions, the new nomination right is a powerful tool that balances their declining influence on the final ballot to some degree (Quinn 2004, pp. 340-341). The heavy concentration of union membership and problematic nature of CLP nominations hand significant power to the leaderships of the "big five" to enable candidacies. However, this gatekeeper power is also largely limited to enabling rather than hindering. As we have seen, union leaderships are hardly unified in their nomination practice, implying that it is unlikely that they would come together to prevent "undesirable" candidacies.

Taken together, the supposedly huge upheavals did not constitute an effective "democratisation". Instead we can observe modest shifts in the power structures between the three major sections, which were guided by ideological conflicts and power considerations between the respective majorities and minorities within those segments. Ed Miliband tried to weaken the unions' influence to improve his public perception, but did so by, depending on the perspective, elaborate or convoluted reform packages in which power gains by members were counterbalanced by tighter nomination control by the PLP, or a further inflation of the selectorate through the 
new registered members section (Dorey and Denham 2016, pp. 266-268). Conversely, Jeremy Corbyn and his supporters tried to strengthen the membership section's influence at the expenses of the PLP (Quinn 2018, pp. 479-480), but had to deal with the unions' separate interests whose support was critical to overcoming his rebellious party in public office. Even Keir Starmer tried to dress his regressive reform package in terms of "democratising" leadership elections by emphasising the need to improve union members' role in these elections and curtailing the influence of extremist "minorities". Therefore, reforms that were supposed to decidedly "democratise" leadership elections merely modified the power distribution between different segments, and the biggest "democratisation" impacts were unintended consequences of rule modifications not associated with this goal.

This reflects the findings of Heppell (2010a, pp. 196-198) and Stark (1996, pp. 64-66) for the 1980s and 1990s. An increasingly fractious party faced a high frequency of leadership elections and the ensuing uncertainty led different sections to seek protection of their own influence by tampering with the electoral rules. This not only had a number of unintended consequences for the outcome of leadership elections, but also provoked similar reactions by other strategic actors. The clearest expression of this is Keir Starmer's latest attempt at reform. This article shows that while his intention was to strengthen the PLP over common party members, his initial proposal, combined with the 2018 measures, would have turned the unions into the most influential force in leadership elections rather than the PLP. Conversely, the revised proposal, specifically the very high PLP threshold coupled with the existing nomination requirements, will serve his intentions far more efficiently than the old electoral college system. So either the initial package was ill-conceived or Starmer showed cunning by cajoling enough union leaderships into supporting a supposedly "watered down" reform proposal that will promote his own interests far better than the initial one.

Funding Open Access funding enabled and organized by Projekt DEAL.

Open Access This article is licensed under a Creative Commons Attribution 4.0 International License, which permits use, sharing, adaptation, distribution and reproduction in any medium or format, as long as you give appropriate credit to the original author(s) and the source, provide a link to the Creative Commons licence, and indicate if changes were made. The images or other third party material in this article are included in the article's Creative Commons licence, unless indicated otherwise in a credit line to the material. If material is not included in the article's Creative Commons licence and your intended use is not permitted by statutory regulation or exceeds the permitted use, you will need to obtain permission directly from the copyright holder. To view a copy of this licence, visit http://creativecommons.org/licen ses/by/4.0/.

\section{References}

Alderman, K., and N. Carter. 1991. A very Tory coup: The ousting of Mrs Thatcher. Parliamentary Affairs 44 (2): 125-139.

Alderman, K., and N. Carter. 1993. The Labour party leadership and deputy leadership elections of 1992. Parliamentary Affairs 46 (1): 49-65.

Alderman, K., and N. Carter. 1995. The Labour party leadership and deputy leadership elections of 1994. Parliamentary Affairs 48 (3): 438-455. 
Bale, T., and P. Webb. 2014. The selection of party leaders in the UK. In The selection of political party leaders in contemporary parliamentary democracies: A comparative study, ed. J.-B. Pilet and W.P. Cross, 12-29. London: Routledge.

Chiru, M., et al. 2015. Explaining change in party leadership selection rules. In The Politics of Party Leadership: A Cross-National Perspective, ed. W.P. Cross and J.-B. Pilet, 31-49. Oxford: Oxford University Press.

Collins, R. 2014. Building a one nation Labour party: The Collins review into Labour party reform. London: Labour Party.

Crines, A., D. Jeffery, and T. Heppell. 2018. The British Labour party and leadership election mandate(s) of Jeremy Corbyn: Patterns of opinion and opposition within the parliamentary Labour party. Journal of Elections, Public Opinion and Parties 28 (3): 361-379.

Cross, W.P., and A. Blais. 2012a. Politics at the centre: The selection and removal of party leaders in the Anglo parliamentary democracies. Oxford: Oxford University Press.

Cross, W.P., and A. Blais. 2012b. Who selects the party leader? Party Politics 18 (2): 127-150.

Cross, W.P., and A. Gaucha. 2021. Selecting party leaders, reform processes and methods: Examining the Australian and New Zealand Labour parties. International Political Science Review 42 (2): 261-276.

Denham, A., and P. Dorey. 2018. Tales of the unexpected: The selection of British party leaders since 1963. British Politics 13 (2): 171-194.

Dorey, P., and A. Denham. 2016. 'The longest suicide note in history': The Labour party leadership election of 2015. British Politics 11 (3): 259-282.

Dorey, P., and A. Denham. 2011. 'O, brother where art thou?': The Labour party leadership election of 2010. British Politics 6 (3): 286-316.

Drucker, H. 1976. Leadership selection in the Labour party. Parliamentary Affairs 29 (4): 378-395.

Drucker, H. 1981. Changes in the Labour party leadership. Parliamentary Affairs 34 (4): 369-381.

Drucker, H. 1984. Intra party democracy in action: The election of the leader and deputy leader by the Labour party in 1983. Parliamentary Affairs 37 (1): 283-300.

Elgot, J. and H. Stuart. 2021. Starmer ditches key part of plan to change Labour leader selection rules. The Guardian, 25 September, https://www.theguardian.com/politics/2021/sep/25/starmer-ditcheskey-part-of-plan-to-change-labour-leader-selection-rules. Accessed 25 September 2021.

Elgot, J., and R. Syal. 2018. Labour members in open revolt at union-backed party rule changes. The Guardian, 23 September, https://www.theguardian.com/politics/2018/sep/23/labour-members-inopen-revolt-at-union-backed-party-reforms. Accessed 26 August 2021.

Hazan, R.Y., and G. Rahat. 2010. Democracy within parties: Candidate selection methods and their political consequences. Oxford: Oxford University Press.

Heppell, T. 2021. The Labour party leadership election: The Stark model and the selection of Keir Starmer. British Politics. https://doi.org/10.1057/s41293-021-00164-w.

Heppell, T. 2010a. Choosing the leader. Labour party leadership elections from Wilson to Brown. London: I.B.Tauris.

Heppell, T. 2010b. Labour leadership elections from Wilson to Brown: Ideological factions and succession planning strategies. Representation 46 (1): 69-79.

Heppell, T., A. Roe-Crines, and D. Jeffery. 2021. Selecting Starmer: The nomination preferences of Labour parliamentarians in the 2020 Labour party leadership election. Representation, advance online publication 31 May. https://doi.org/10.1080/00344893.2021.1927809.

Jobson, R., and M. Wickham-Jones. 2011. Reinventing the block vote? Trade unions and the 2010 Labour party leadership election. British Politics 6 (3): 317-344.

Johnston, N. 2020. Leadership elections: Labour party. London: House of Commons Briefing Papers no 03938.

Joyce, E. 2013. Unite in Falkirk: Amateur and irresponsible. The Guardian, 5 July. https://www.theguardian.com/commentisfree/2013/jul/05/unite-falkirk-irresponsible-labour. Accessed 26 August 2021.

Katz, R.S., and P. Mair. 1993. The evolution of party organizations in Europe: The three faces of party organization. The American Review of Politics 14 (4): 593-617.

Kenig, O. 2008. Democratization of party leadership selection: Do wider selectorates produce more competitive contests? Electoral Studies 28: 240-247.

Kenig, O., G. Rahat, and R.Y. Hazan. 2015a. Leadership selection versus candidate selection: Similarities and differences. In Party primaries in comparative perspective, ed. G. Sandri, A. Seddone, and F. Venturino, 21-39. Farnham: Ashgate. 
Kenig, O., G. Rahat, and O. Tuttnauer. 2015b. Competitiveness of party leadership selection processes. In The politics of party leadership: A cross-national perspective, ed. W.P. Cross and J.-B. Pilet, 50-72. Oxford: Oxford University Press.

Labourlist. 2015. Number of voters in leadership contest revised down to 550,000. Labourlist, 25 August. https://labourlist.org/2015/08/number-of-voters-in-leadership-contest-revised-down-to-550000/. Accessed 10 June 2020.

Labour Party. 2021. How we work: Members of the NEC. Labour party. https://labour.org.uk/about/howwe-work/national-executive-committee/whos-on-the-nec/. Accessed 09 January 2021.

Labour Party. 2020a. Labour Party Rule Book 2020. London: Labour Party.

Labour Party. 2020b. Leadership election 2020_Candidate codes of conduct. London: Labour Party.

LeDuc, L. 2001. Democratizing party leadership selection. Party Politics 7 (3): 323-341.

Lisi, M., A. Freire, and O. Barberà. 2015. Leadership selection methods and party types. In The politics of party leadership: A cross-national perspective, ed. W.P. Cross and J.-B. Pilet, 12-30. Oxford: Oxford University Press.

Ludlam, S., and A. Taylor. 2003. The political representation of labour interests in Britain. British Journal of Industrial Relations 41 (4): 727-749.

Pemberton, H., and M. Wickham-Jones. 2015. Factionalism in the Parliamentary Labour Party and the 2015 leadership contest. Renewal 23 (3): 5-21.

Pemberton, H., and M. Wickham-Jones. 2013. Brothers all? The operation of the electoral college in the 2010 Labour leadership contest. Parliamentary Affairs 66 (4): 708-731.

Pilet, J.-B., and W.P. Cross. 2014. The selection of party leaders in comparative perspective. In The selection of political party leaders in contemporary parliamentary democracies: A comparative study, ed. J.-B. Pilet and W.P. Cross, 222-239. London: Routledge.

Punnett, R.M. 1990. Selecting a leader and deputy leader of the Labour party: The future of the electoral college. Parliamentary Affairs 43 (2): 175-195.

Punnett, R.M. 1992. Selecting the party leader: Britain in comparative perspective. London: Harvester Wheatsheaf.

Punnett, R.M. 1993. Selecting the party leader in Britain: A limited participatory revolution. European Journal of Political Research 24 (3): 257-276.

Quinn, T. 2018. From the Wembley conference to the 'McDonnell amendment': Labour's leadership nomination rules. The Political Quarterly 89 (3): 474-481.

Quinn, T. 2016. The British Labour party's leadership election of 2015. British Journal of Political Science and International Relations 18 (4): 759-778.

Quinn, T. 2012. Electing and ejecting party leaders in Britain. Basingstoke: Palgrave MacMillan.

Quinn, T. 2004. Electing the leader: The British Labour party's electoral college. British Journal of Political Science and International Relations 6 (1): 333-352.

Rahat, G., R.Y. Hazan, and R.S. Katz. 2008. Democracy and political parties. On the uneasy relationships between participation, competition and representation. Party Politics 14 (6): 663-683.

Stark, L.P. 1996. Choosing a leader. Party leadership contests in Britain from Macmillan to Blair. Basingstoke: Macmillan Press.

Sparrow, A. 2020. Labour leadership contest: We failed on Russia under Corbyn's leadership, says Nandy-Live news. The Guardian, 15 January, https://www.theguardian.com/politics/live/2020/jan/ 15/pmqs-boris-johnson-corbyn-labour-trump-praises-boris-johnson-for-suggesting-us-should-draftnew-iran-deal-live-news?page = with:block-5e1f3c6c8f0852212f74e954\#block-5e1f3c6c8f08522 12f74e954. Accessed 26 August 2021.

Sparrow, A. 2016. Jeremy Corbyn sweeps to victory increasing his mandate as Labour leader-As it happened. The Guardian, 24 September, https://www.theguardian.com/politics/blog/live/2016/sep/24/ labour-leadership-election-result-jeremy-corbyn-owen-smith-appeals-for-unity-politics-live?page= with:block-57e6463ae4b0831a51401d5d\#block-57e6463ae4b0831a51401d5d. Accessed 26 August 2021.

Seyd, P. 2020. Corbyn's labour party: Managing the membership surge. British Politics 15 (1): 1-24.

Publisher's Note Springer Nature remains neutral with regard to jurisdictional claims in published maps and institutional affiliations. 